\title{
Sosialisasi dan Simulasi Menabung Rumah Yatim Kota Bekasi
}

\author{
Bintang Narpati \\ Universitas Bhayangkara Jakarta Raya, $\underline{\text { b.narpati@gmail.com }}$
}

\begin{abstract}
Abstrak
Kegiatan Pengabdian Kepada Masyarakat ini bertujuan untuk mendidik sejak dini khususnya anak - anak sekolah menengah pertama dan atas untuk gemar menabung dan hidup hemat. Perkembangan teknologi dan informasi saat ini bagaikan air mengalir yang deras yang tidak bisa dibendung. Dari kota besar hingga pelosok desa beragam informasi yang didapat oleh sebagian masyarakat menjadikan mereka mengikuti trend untuk dijadikan style atau gaya hidup saat ini. Trend sosialita jaman sekarang atau gaya hidup jaman sekarang adalah terjadinya pengeluaraan belanja atau sikap konsumtif yang berlebihan. Sikap ini umumnya terjadi pada usia anak - anak, remaja hingga dewasa yang tidak kita sadari. Pendapatan yang tidak seimbang dengan pengeluaran akan mengakibatkan terjadinya masalah dalam kehidupan di mana kehidupan tidak akan nyaman dengan hutang yang semakin menumpuk. Permasalahannya adalah apabila sikap boros, gaya hidup mewah dan sikap konsumtif yang berlebihan yang tidak dapat ditekan sedini mungkin akan mengakibatkan kehancuran kehidupan dimasa yang akan datang. Melalui Pengabdian Kepada Masyarakat Universitas Bhayangkara Jakarta Raya yang mengarah kepada anak - anak yatim khususnya di kota Bekasi, dilakukan sosialisasi menabung dengan lokasi Rumah Yatim Bekasi dan dilakukan ceramah dan diskusi mengenai pentingnya arti menabung, selain itu dilakukan pula simulasi tentang bagaimana petugas bank melayani pembukaan rekening nasabah. Hal ini dilakukan agar sejak usia dini, anak - anak yatim sudah terbiasa menabung dan terbiasa datang ke bank untuk menabung dan melakukan transaksi lainnya. Hasil sosialisasi dan simulasi menabung ini bertujuan agar anak - anak yatim dapat hidup hemat tidak melakukan pemborosan terhadap dana - dana yang telah dimilikinya baik dana yang didapat melalui para dermawan ataupun penjualan barang atas hasil karyanya dengan tujuan agar dana tersebut dapat ditabung dan dapat dikelola serta dimanfaatkan untuk keperluan sesuai dengan kebutuhannnya.

Kata kunci: Sosialisasi, Simulasi, Menabung
\end{abstract}

\begin{abstract}
Community Service Activities aims to educate early on, especially high school children and above to like saving and live frugally. The development of technology and information today is like a flowing water that can not be dammed. From the big cities until remote villages of information received by some people make them follow the trend to be a style or lifestyle today. Today's socialite trend or lifestyle today is the occurrence of expenditure spending or excessive consumerist attitudes. This attitude is mostly happening at the age of children, adolescents to adults who not aware of unbalanced revenues with expenditure will lead to
\end{abstract}




\section{JURNAL ABDIMAS UBJ}

problems in life where life will not be comfortable with increasingly heaped debts. The problem is that the extravagance, luxurious lifestyle and excessive consumptive attitudes that can not be suppressed as early as possible will lead to the destruction of life in the future. Through Community Service Bhayangkara University of Jakarta Raya that leads to orphans, especially in the city of Bekasi, the socialization of saving with the location of Rumah Yatim Bekasi and conducted lectures and discussions about the importance of the saving, but also simulations of how the bank officer serving customer account opening. This is done so that from an early age, orphans are accustomed to saving and accustomed to come to the bank to save and doing other transactions. The results of socialization and simulation of saving is intended so that orphans can live frugally do not waste the funds that have been owned either the funds obtained through the benefactor or the sale of goods on his work with the aim that the funds can be saved and can be managed and utilized for the purposes of its needs.

Keywords: Socialization, Simulation, Saving

\section{Pendahuluan}

Dalam berbagai wilayah baik di dunia maupun di Indonesia kehidupan masyarakatnya memiliki warisan luhur ataupun budaya daerahnya masing masing baik dalam hal cara bermasyarakat, bekerja, transportasi dan lain - lain hampir setiap daerah memiliki keunikan pada daerahnya masing - masing. Sejalan dengan perkembangan teknologi dan informasi yang begitu pesat, maka daerah daerah tersebut yang semula masih kental dengan warisan luhur dan budayanya lambat laun dapat bergeser mengikuti arus informasi yang diterima tadi dengan mudahnya karena dapat mengakses informasi tersebut melalui media elektronik, cetak ataupun melalui informasi lainya.

Perkembangan teknologi dan informasi bagi sebagian masyarakat khususnya di Indonesia memliki tata cara pandang yang berbeda ada yang menganggap baik dan bermanfaat terhadap informasi tersebut disamping itu terdapat pula informasi yang tidak baik atau bahkan dapat merusak generasi muda.

Misal informasi yang dapat dijumpai dalam media elektronik maupun cetak adalah trend gaya hidup mewah yang sebagian melanda kota - kota besar di Indonesia bahkan sudah sampai ke pelosok desa. Akibat dari trend gaya hidup ini maka pola hidup yang semula dari sederhana bisa menjadi gaya hura - hura atau pemborosan.

Seseorang yang berpenghasilan untuk memenuhi kehidupan sehari - harinya saja belum tentu mencukupi namun karena mengikuti gaya trend masa kini yaitu pola hidup konsumtif maka orang tersebut akan mengikutinya dengan cara membeli sesuatu yang mungkin dalam perolehannya orang tersebut harus rela berhutang ke sana kesini demi mendapatkan barang tersebut sehingga orang tersebut ingin dikatakan tidak ketinggalan jaman. Dalam hal ini pola menabung belum mengena pada diri orang tersebut.

Pola hidup konsumtif sebagian masyarakat di Indonesia walaupun sudah mengenal perbankan namun masih terdapat kesulitan untuk membudayakan kebiasaaan menabung sehingga dapat menimbulkan kesan pola hidup konsumtif atau sifat boros dan dapat pula dikatakan bahwa pengeluaran belanja mereka 


\section{JURNAL ABDIMAS UBJ}

hampir sama dengan pendapatan yang mereka terima atau pengeluaran belanja melebih dari pada pendapatan.

Parahnya lagi, masyarakat juga tergolong boros. Di mana porsi belanja mereka nyaris sama dengan pendapatan. Penggabungan antara pengeluaran dan pendapatan inilah yang memotivasi Bank Indonesia untuk mengkampanyekan program Ayo Menabung (DetikFinance 2011). Program ini dilakukan melalui bank bank umum dan disosialisaikan kepada masyarakat dengan tujuan agar masyarakat dapat kembali menyisihkan dananya untuk ditabung. Masyarakat di suatu Negara dapat diukur tingkat konsumtifnya yaitu total konsumsi dibagi pendapatan nasional. Bila lebih besar tingkat konsumsinya maka budaya menabung harus ditingkatkan sehingga program gemar menabug tidak hanya ada di dalam negeri saja namun diupayakan sampai ke luar negeri agar masyarakat Indonesia dan dunia gemar menabung.

Menabung pada dasarnya dapat meningkatkan pertumbuhan ekonomi suatu negara dengan cara menginvestasikan dana tersebut kepada produk - produk yang dikeluarkan oleh lembaga keuangan maupun pemerintah. Bila nasabah giat menabung maka dana dan kemudian menginvestasikan dananya maka dorongan pertumbuhan ekonomi akan semakin cepat (Todaro. 1983).

Menabung sangat diperlukan baik oleh individu maupun secara lembaga yang ingin berinvestasi di berbagai bidang karena untuk berinvenstasi diperlukan dana yang cukup dari hasil menabung. Bila tidak ada tabungan maka untuk berinvestasi mungkin akan dilakukan pnjaman hutang kepada lembaga lain atau orang lain. Tabungan menurut Bastian dan Suhardjono (2006) adalah dana yang disimpan oleh masyarakat pada suatu lembaga keuangan dengan syarat tertentu dan untuk penarikan dana tersebut dapat melalui sarana yang diberikan oleh lembaga keuangan dengan waktu sesuai yang diinginkan nasabah.

Pengabdian Kepada Masyarakat kota Bekasi yang dilakukan oleh Universitas Bhayangkara Jakarta Raya ditujukan terhadap anak - anak yatim sebagai peserta pelatihan. Rumah Yatim Bekasi yang terletak di jalan Veteran Bekasi ini, menampung anak - anak yatim dan piatu dan juga kaum dhuafa. Selain kegiatannya sebagai rumah yatim, lembaga ini juga menerima infaq, zakat dan shodaqoh bagi para dermawan atau donatur yang ingin menyisihkan sebagian rezekinya sebagai amal ibadah. Rumah Yatim Bekasi merupakan suatu lembaga dan fasilitator membantu anak - anak yatim dan kaum dhu'afa untuk mendapatkan haknya dan mendapatkan pendidikan yang layak pada lembaga ini.

Undang - Undang Negara RI No. 10 Tahun 1998/10 November 1998 tentang perbankan mengatakan bahwa lembaga bank merupakan badan usaha dengan kedudukan hokum dan kegiatannya adalah menghimpun atau menarik dana dari nasabah (masyarakat) dalam bentuk tabungan atau simpanan dan menyalurkan dananya kembali kepada nasabah atau masyarakat dalam bentuk pinjaman atau kredit ataupun bentuk lainnya yang bertujuan meningkatkan taraf hidup nasabah atau masyarakat

Kegiatan bank ini merupakan menghimpun dana dari masyarakat berupa simpanan (giro, tabungan, deposito) dan memberikan dana kepada masyarakat 


\section{JURNAL ABDIMAS UBJ}

seperti kredit usaha, modal kerja dan investasi serta memberikan jasa bank lainnya seperti bunga dan jasa operasional (Kasmir 2002).

Sedangkan dalam pemberian dana, diberikan pinjaman kepada nasabah atau masyarakat sesuai dengan plafon yang ditujukan kepada nasabah. Ada yang kredit usaha kecil (micro), menengah dan corporate tergantung dari jenis kebutuhan bagi nasabahnya. Jasa - jasa perbankan lainnya adalah memberikan kelancaran operasional perbankan untuk memudahkan masyarakat bertransaksi.

Bank umum adalah lembaga perantara keuangan dengan para nasabah yang tujuan untuk menerima simpanan uang nasabah, meminjamkan uang kepada nasabah dan dapat menerbitkan cek (cheque) dan giro bilyet atau bilyet giro.

Industri perbankan saat ini mengalami perubahan yang cukup besar dari tahun ke tahun dan menjadi lebih kompetitif disebabkan adanya kebijakan ataupun peraturan - peraturan perbankan sehingga dalammenjalankan oeprasionalnya bank memiliki fleksibilitas layanan yang mereka tawarkan kepada masyarakat, dengan memiliki cabang - cabang hamper diseluruh wilayah Indonesia bahkan sampai luar negeri dengan tarif jasa yang berbeda - beda pada masing - masing bank.

Salah satu produk simpanan bank adalah Tabungan yang merupakan simpanan dana nasabah dan penarikannya hanya dapat dilakukan dengan alat alat tertentu yang telah disepakati. Bagi masing - masing individu dianjurkan dapat menyisihkan penghasilannya setiap bulan untuk menabung walaupun relatif dikatakan tidak banyak namun diusahakan ada saldo yang tersisa atau tersimpan setiap bulan pada buku tabunganya. Hal ini mungkin buat sebagain orang sulit dilakukan namun bila terbiasa akan mudah dilakukan dan dapat diambil manfaatnya.

Melalui menabung mengajarkan seseorang hidup berhemat dan tentunya mengelola atau mengatur keuangan. Selain itu juga dapat membiasakan diri menjadi hidup lebih hemat atau tidak boros atau konsumtif. Pengeluaran belanja disesuaikan dengan pendapatan atau penghasilan dari pekerjaan yang diterima yang digunakan untuk pemenuhan kebutuhan hidup sehari - hari. Selain itu, manfaatnya adalah sejak usia dini, anak akan terbiasa menghemat pengeluaran, disiplin dan mengelola pengeluaran untuk kebutuhan yang dianggap sangat perlu (mendesak).

Beberapa manfaat dari menabung yang dilakukan sejak dini antara lain:

1. Sebagai Dana Pensiun

Kebiasaan menabung sejak dini memberikan manfaat sebagai dana pensiun dikemudian hari. Hal ini dapat dilakukan dengan menabung pada bank - bank umum yang memiliki produk tabungan rencana ataupun tabungan pensiun. Dengan tabungan rencana atau pesiunan tersebut maka dana nasabah akan dikembangkan oleh bank dan biasanya ditambahkan oleh bank yaitu asuransi jiwa sebagai minat dari nasabah untuk menabung dananya yang disimpan selama 5 (lima) tahun sampai dengan 20 (dua puluh) tahun.

2. Untuk keadaan berjaga - jaga atau darurat

Dengan memiliki dana yang cukup dalam tabungan maka seseorang dapat mengatisipasi kebutuhan yang mendesak. Jadi memiliki tabungan pada saat - 


\section{JURNAL ABDIMAS UBJ}

saat keadaan darurat atau mendesak sangat diperlukan karena seseorang tidak perlu melakukan pinjaman kepada orang lain ataupun lembaga keuangan.

4. Untuk keperluan Hiburan

Dalam kebutuhan hidup seseorang, diperlukan pula hiburan sebegai refreshing atau menyenagkan hati sehingga segala pekerjaan dapat dilupakan dahulu untuk sementara agar pikiran kembali menjadi segar. Biasanya hal ini dilakukan pada saat - saat liburan sekolah ataupun cuti pekerjaan ataupun mungkin pada hari lain yang dianggap sesuai dengan keinginan seseorang. Dalam melakukan hal itu maka diperlukan dana yang cukup untuk dapat menikmati hiburan yang akan dijalani. Bila seseorang memiliki tabungan untuk tujuan hiburan ini, maka dengan mudah akan mengeluarkannya sesuai dengan kebutuhannya.

5. Dana yang dapat digunakan sebagai investasi

Adanya peluang usaha membuat sebagian orang berpikir untuk mendapatkannya dengan harapan bahwa adanya keuntungan setelah menanamkan investasi atau melakukan usaha secara sendiri ataupun berkelompok. Bila memiliki dana yang cukup untuk melakukan bisnis maka kemungkinan besar harapan untuk mendapatkan keuntungan ada namun sebaliknya bila tidak memiliki dana maka peluang usaha akan hilang dan tidak akan mendapatkan keuntungan yang diharapkan.

Sebagai syarat untuk memiliki tabungan, maka masyarakat yang ingin melakukan pembukaan rekening pada bank, diberikan peraturan oleh masing masing bank yaitu:

a. Adanya setoran awal

b. Memiliki Kartu Identitas yang masih berlaku:

c. Memiliki Nomor Pokok Wajib Pajak (NPWP)

d. Memiliki nomor telepon yang bisa dihubungi (biasanya Telkom)

e. Dikenakan biaya administrasi bulanan.

Bila persyaratan tersebut telah dipenuhi oleh nasabah, maka bank akan memberikan sarana Tabungan untuk melakukan transaksi yaitu:

1. Buku Tabungan

2. Slip / nota penarikan

3. ATM (Automatic Teller Machine)

4. Sarana lainnya (Formulir nota kirim uang/Transfer, Internet Banking, Mobile Banking / HP, dll)

Bagi sebagian nasabah terkadang dengan adanya sarana penarikan tabungan ini sering dijumpai nasabah dengan leluasa menarik ataupun transaksi lainnya melalui ATM, e-channel (internet banking dan SMS banking). Hal tersebut merupakan hak dari nasabah karena nasabahlah yang memiliki dananya namun yang perlu ditekankan bahwa penggunaan ATM atau sarana lainnya dalam pengambilan ataupun transaksi lainnya hendaklah digunakan secara bijak.

Beberapa faktor yang dapat menentukan tingkat peminatan seseorang menabung di bank adalah:

a. Penghasilan 


\section{JURNAL ABDIMAS UBJ}

Masyarakat yang memiliki penghasilan tinggi dibanding dengan penghasilan rendah terkadang berbeda pandangan dalam menabung di bank. Masyarakat berpenghasilan tinggi sebagian besar cenderung menabung di bank walaupun terkadang dana yang ada di tabungan akan dibelanjakannyan pula melalui sarana ATM ataupun lainnya sehingga menyisakan saldo minimum. Namun masyarakat dengan penghasilan rendah terkadang cenderung tidak menabung di bank dikarenakan untuk menutupi kebutuhan hidup sehari - hari saja belum mencukupi. Namun semua ini tergantung pada kemauan bagi masing - masing individu apakah mau menabung atau tidak.

b. Suku bunga bank

Banyak masyarakat di sekitar kita cenderung menginginkan bunga yang tinggi dari bank, apabila suku bunga bank naik maka nasabah banyak datang ke bank namun sebaliknya bila suku bunga bank turun banyak pula sebagian dana nasabah dialihkan ke investasi lainnya misalnya dalam bentuk pembelian surat berharga, saham, obligasi, emas dan instrumen lainnya.

c. Tingkat kepercayaan terhadap bank

Trust atau kepercayaan adalah kunci utama suatu bank dalam menarik dana nasabah, karena bila bank tersebut pernah memiliki masalah maka adanya kecenderungan nasabah memiliki kepercayaan yang menurun terhadap bank tersebut sehingga nasabah banyak mengalihkan dananya ke lembaga keuangan lainnya.

Tujuan kegiatan Pengabdian Kepada Masyarakat ini adalah memperkenalkan kepada anak - anak yatim produk - produk perbankan terutama tabungan karena tabungan ini akan sering digunakan sebagai transaksi keuangan baik menyimpan ataupun menyetor uang.

Manfaat yang didapat bagi masyarakat dari kegiatan ini adalah:

1. Mengajak anak - anak yatim untuk berperan aktif melakukan menabung sejak dini.

2. Anak - anak yatim diharapkan dapat menyadari bahwa pentingnya menabung agar dapat menghemat keuangan bagi individu masing - masing.

3. Anak - anak yatim diharapkan dapat menabung di bank dalam hal peningkatan potensi diri dan dapat memahami pentingnya menabung dalam kehidupan sehari-hari.

4. Melalui sosialisasi dan simulasi pengenalan tabungan ini, diharapkan akan menambah rasa kepedulian terhadap pentingnya motivasi untuk terus belajar dan berlatih dalam meningkatkan kualitas diri.

\section{Metode Pelaksanaan}

Kegiatan Pengabdian Kepada Masyarakat berupa sosialisasi dan simulasi tabungan dengan peserta didik adalah anak - anak yatim di Rumah Yatim Bekasi yang berlokasi di Jalan Veteran Margahayu Bekasi Selatan. Peserta merupakan anak - anak yatim yang terdiri dari rata - rata usia setingkat SMP dan SMA terdiri dari 15 (lima belas) orang siswa SMP dengan komposisi siswa perempuan 8 (delapan) orang atau 53\% dan siswa laki - laki sebanyak 7 (tujuh) orang atau $47 \%$. Sedangkan untuk siswa SMA berjumlah 10 (sepuluh) orang terdiri dari 7 (tujuh) siswa 


\section{JURNAL ABDIMAS UBJ}

perempuan atau 70\% dan 3 (tiga) orang siswa laki - laki atau 30\% yang ditunjukkan pada Tabel 1. Peserta kegiatan ini dikhususkan pada siswa/i sekolah menengah pertama dan atas karena pada usia tersebut dapat ditanamkan kebiasaan menabung sejak dini.

Tabel 1. Sosialisasi dan Simulasi Menabung

\begin{tabular}{|l|c|c|c|c|}
\hline Peserta & SMP & \%-tase & SMA & $\%$-tase \\
\hline Perempuan & 8 & $53 \%$ & 7 & $70 \%$ \\
\hline Laki - Laki & 7 & $47 \%$ & 3 & $30 \%$ \\
\hline Total & 15 & & 10 & \\
\hline
\end{tabular}

Metode pengabdian kepada masyarakat yang telah dilakukan ini menggunakan metode ceramah, role play yang dipraktekkan oleh peserta dan nara sumber serta tanya jawab. Metode ceramah digunakan menyampaikan pengetahuan secara umum tentang materi pembukuan sederhana dan soosialisasi tabungan meliputi pencatatan jurnal penerimaan dan pengeluaran kas, rekonsiliasi antara pencatatan pembukuan dengan buku tabungan bank dan produk dan jasa perbankan lainnya.

Berikut ini adalah rincian tahapan sosialisasi dan simulasi menabung Pengabdian Kepada Masyarakat yang telah dilakukan yaitu:

1. Sebelum dilakukan pemberian materi dilakukan registrasi dan pretest terlebih dahulu untuk mengetahui sampai sejauh mana pengetahuan perbankan khususnya tabungan dari masing - masing peserta.

2. Pemberian materi mengenai pengetahuan perbankan dan sosialisasi tabungan kepada peserta didik dan dilakukan pula sesi tanya jawab antara nara sumber dan peserta didik yang diselingi dengan games (permainan - permainan) yang menambah suasana terkesan tidak kaku namun materi tetap sampai kepada peserta didik sehingga lebih mudah dipahami.

3. Role play perbankan dilakukan oleh masing - masing peserta dengan dipandu oleh nara sumber yang bertujuan agar masing - masing peserta mengenal lebih jauh tentang kantor cabang perbankan sehingga kedepannya untuk melakukan transaksi perbankan sudah familiar sehingga tidak kaku (canggung). Role play diperankan oleh masng - masing peserta didik dengan disaksikan oleh peserta didik lainnya. Masing - masing peserta didik ada yang berperan sebagai security bank, teller dan customer service.

4. Transaksinya dimulai dari kesiapan security yang menyambut baik nasabah bank yang datang dan dipandu untuk ke customer service untuk melakukan pembukaan rekening sampai dengan mendapatkan buku tabungan bank.

5. Transaksi selanjutnya yaitu penyetoran awal tabungan dan dilanjutkan dengan transaksi lainnya yaitu penarikan tabungan pada teller.

6. Setelah semua kegiatan selesai dilaksanakan kemudian dilakukan post test untuk mengetahui sampai sejauh mana peningkatan pengetahuan mengenai pembukuan dan pengenalan perbankan (tabungan). 


\section{JURNAL ABDIMAS UBJ}

\section{Hasil dan Pembahasan}

Hasil yang didapat dari kegiatan ini disajikan dalam bentuk angka, grafik dan tabel dengan tujuan agar pembaca dapat membacanya dan memahami dengan mudah. Pada pembahasan dibuat dengan beberapa sub-bab. Pada hakekatnya, kegiatan ini merupakan cara untuk meningkatkan ilmu pengetahuan dan ketrampilan anak - anak yatim di Rumah Yatim Bekasi. adalah:

Adapun perubahan pasca pelatihan kegiatan ini bagi anak - anak yatim

1. Memahami pengetahuan tentang tabungan dan produk bank lainnya.

2. Memahami cara membuka rekening di bank dan mengetahui petugas - petugas bank yang menangani pembukaan rekening dan transaksi keuangan melalui simulasi bank.

3. Menyadari pentingnya menabung dan menanamkan kebiasaan menabung dalam kehidupan sehari - hari.

4. Sebelum dilakukan kegiatan sosialisasi dan simulasi ini, masing - masing peserta didik (anak - anak yatim) diberikan soal awal (pretest) dengan tujuan untuk mengukur sejauh mana pengetahuan mereka mengenai perbankan dan produk produknya terutama tabungan. Kemudian dilanjutkan dengan sosialisasi tabungan yang diberikan oleh nara sumber yaitu dosen dari Fakultas Ekonomi Universitas Bhayangkara Jakarta Raya dan dilanjutkan dengan simulasi dengan melibatkan anak - anak yatim yang berperan sebagai Security Bank, Customer Service dan Teller. Setelah selesai kegiatan tersebut kemudian dilakukan tes akhir (post test) untuk melihat perkembangan pemahaman dan pengetahuan peserta didik. Dari hasil pre-tes dan post-tes terlihat adanya peningkatan hasil yang signifikan tentang pengetahuan produk tabungan dan bank setelah diberikan sosialisasi dan simulasi kegiatan bank yang ditunjukkan pada Tabel 2 yaitu rata - rata nilai pretest adalah 4,68 sedangkan rata - rata post test nya adalah 8,36 atau terjadi peningkatan sebesar $78,63 \%$.

5. Sosialisasi dan simulasi yang telah dilaksanakan, selanjutnya dimonitoring perkembangan masing - masing anak yatim dengan cara menghubungi kepala Asrama Rumah Yatim Bekasi yang dilakukan seminggu sekali kemudian sebulan sekali sampai diperoleh hasil yang diinginkan yaitu adanya keinginan dan kebiasaan menabung.

6. Melalui pembinaan yang kontinyu terhadap perkembangan anak - anak yatim ini diharapkan dapat menjadikan mereka, manusia yang tangguh dan mandiri, yang dapat menjawab tantangan jaman. 


\section{JURNAL ABDIMAS UBJ}

Tabel 2. Pre test dan post test Tabungan

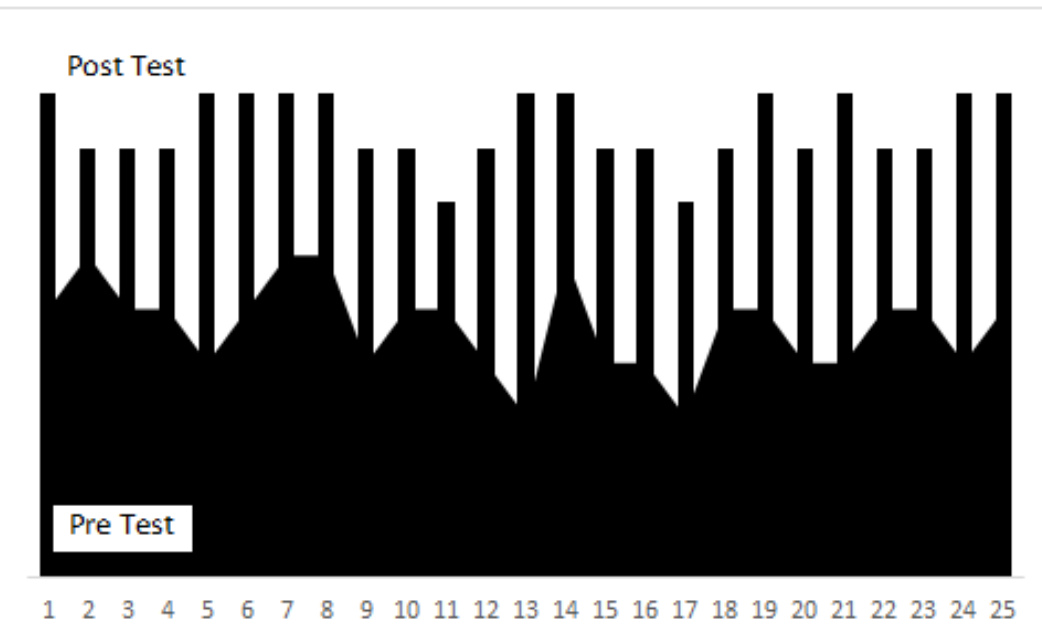

\section{Simpulan dan Rekomendasi}

Kesimpulan dari Pengabdian Kepada Masyarakat pada Rumah Yatim Bekasi ini yaitu peserta didik atau anak - anak yatim termotivasi untuk dapat mengenal bank dan tabungan lebih jauh walaupun masih memiliki pengetahuan yang masih terbatas terhadap produk bank khususnya tabungan. Menanamkan pentingnya menabung sejak dini merupakan kesadaran yang perlu dipupuk bagi anak - anak yatim untuk berprilaku tidak boros. Melalui kegiatan sosialisasi dan simulasi ini, peserta didik lebih mudah memahami mengenai bank dan tabungan. Dalam sikap untuk menabung ada beberapa faktor yang mempengaruhinya antara lain pelayanan, keyakinan dan lokasi / jarak (Dita Pertiwi. 2012).

Rekomendasi yang dibutuhkan dalam kegiatan ini yaitu diperlukan pendampingan ataupun penyuluhan agar pengetahuan peserta didik atau anak anak yatim mengenai bank dan tabungan dapat mengenal lebih mendalam dan meningkatkan disiplinnya dalam menabung. Pemberian dana oleh donatur kepada anak - anak yatim dapat disetorkan bank dengan didampingi petugas lembaga Rumah Yatim Bekasi. Untuk lebih memberikan jiwa kemandirian, perlunya memberikan jiwa kewirausahaan bagi anak - anak yatim untuk dapat lebih mandiri atau tidak terlalu bergantung kepada lembaga Rumah Yatim Bekasi. Pembinaan terhadap anak - anak yatim melalui pelatihan kerja setelah lulus sekolah untuk menghasilkan tenaga terdidik dan memiliki kemampuan (skill) pada bidangnya agar menjadi tenaga siap pakai dalam lapangan kerja. Mengadakan seminar merupakan cara alternatif untuk menambah pengetahuan tentang keuangan, sikap dan perilaku peserta didik (Hani Sirine dan Dwi Setiyani Utami. 2016).

\section{Daftar Pustaka}

Bastian, Indra dan Suhadjono, 2006. Akuntansi Perbankan. Salemba Empat, Jakarta.

DetikFinance. 2011. Potret Masyarakat Indonesia: Tak Gemar Menabung dan Boros. 


\section{JURNAL ABDIMAS UBJ}

Kasmir, 2002. Bank E Lembaga Keuangan Lainnya. Edisi keenam, PT. Raja Garfindo PersaSda, Jakarta.

Pertiwi, Dita, 2012. Analisis Minat Menabung Masyarakat pada Bank Muamalat di Kota Kisaran. Jurnal Ekonomi dan Keuangan Vol.1 No.1.

Sirine, Hani dan Utami, Dwi Setiyani, 2016. Faktor - faktor yang Mempengaruhi Perilaku Menabung di Kalangan Mahasiswa. Volume XIX No.1, April 2016. ISSN 1979-6471

Todaro, M. P. 1983. Ekonomi Pembangunan di Dunia Ketiga. Jakarta: Penerbit Balai Aksara.

Undang - Undang Negara Republik Indonesia Nomor 10 Tahun 1998 Tanggal 10 November 1998. 